\title{
Jadwal Distribusi dan Citarasa Makanan Berhubungan dengan Sisa Makanan Pasien di Ruang Perawatan Obgyn dan Bedah RSD. dr. Soebandi Jember
}

\section{The Distribution Schedule and Food Taste was Correlated with Patient's Plate Waste at Obstetric and Surgical Room in dr. Soebandi Hospital, Jember}

\author{
Arinda Lironika*1, Mailia Yunda Suryadi²
}

\begin{abstract}
ABSTRAK
Latar Belakang : Penerimaan makanan rumah sakit masih menjadi masalah serius. Daya terima pasien ditunjukkan dengan banyak sedikitnya makanan tersisa. Tingginya sisa makanan menyebabkan ketidaksesuaian asupan dengan kebutuhan gizi yang akhirnya berdampak malnutrisi. Sisa makanan pasien di ruang obgyn dan bedah masih tinggi $\geq 20 \%$. Jadwal distribusi dan citarasa makanan kemungkinan menjadi faktor penyebabnya.

Tujuan : Menganalisis hubungan jadwal distribusi dan citarasa makanan dengan sisa makanan pasien di ruang perawatan obgyn dan bedah RSD. dr Soebandi Jember.

Metode : Jenis penelitian ini survey analitik dengan rancangan cross sectional study. Sampel berjumlah 51 orang, diambil dengan teknik purposive samping. Sampel adalah pasien obsgyn dan bedah berumur 18-60 tahun, mendapat makanan biasa dan kondisi sadar. Jadwal distribusi didapatkan dengan mengamati ketepatan waktu distribusi makanan mulai dari dapur instalazi gizi hingga makanan sampai kepada pasien selama 3 hari. Citarasa makanan diperoleh melalui wawancara dan kuesioner. Pengukuran sisa makanan menggunakan visual comstock. Data dianalisis dengan uji korelasi Rank Spearman. Hasil : Rata-rata sisa makanan pasien di ruang obgyn dan bedah $27,6 \%$. Sisa makanan pada pasien laki-laki dan perempuan berbeda signifikan $(p=0,001)$. Sebanyak $52,9 \%$ pasien yang sisa makanannya banyak, mendapatkan makanan dengan jadwal distribusi yang tepat. Jadwal distribusi tidak berhubungan signifikan dengan sisa makanan $(p=0,218)$. Subyek yang menilai citarasa makanannya baik, hampir semuanya $(71,4 \%)$ menyisakan sedikit makanan. Terdapat korelasi positif yang signifikan antara citarasa makanan dengan sisa makanan $(p=0,001 ; r=0,471)$.

Kesimpulan : Jadwal distribusi makanan tidak berhubungan dengan sisa makanan pasien. Namun, citarasa makanan berhubungan dengan sisa makanan. Semakin baik citarasa makanan semakin sedikit sisa makanan.
\end{abstract}

Kata kunci : Citarasa makanan, jadwal distribusi, sisa makanan

\section{ABSTRACT}

Background : The hospital food acceptance is still a serious problem. The patient's acceptance is indicated by the least amount of plate waste. High plate waste causes an intake incompatibility with nutritional needs, which ultimately affects malnutrition. The patient's plate waste in obstetric and surgical room is still high $\geq 20 \%$. The distribution timetable and food taste maybe a contributing factor.

Objectives : To analyzed the correlation of distribution timetable and food taste with patient's plate waste at obstetric and surgicall room in dr. Soebandi Hospital, Jember

Methods: This study was an analytical survey with a cross sectional design. The sample was 51 subjects, taken by a purposive sampling. Sample were obstetric and surgical patients aged 18-60 years, received regular food and were in a conscious. The distribution timetable was obtained by observing the accuracy of food distribution time span from the kitchen of nutrition instalation untill food arrived at the patient for 3 days. Food taste was obtained through interviews and questionnaires. Plate waste was measured by visual comstock. Data were analyzed by Rank Spearman test.

Results : The average plate waste of patients is $27.6 \%$. The plate waste in male and female patient was significantly different ( $p=0.001$ ). $52.9 \%$ subjects with large amounts of plate waste, get hospital food with the right distribution time. The distribution timetable wasn't significantly correlated with plate waste $(p=0.218)$. Subjects who considered their food taste good, almost all (71.4\%) left little food. There was a significant positive correlation between taste of food and plate waste $(p=0.001 ; r=0.471)$.

Conclusions: Food distribution timetable isn't related to patient's plate waste. However, food taste is correlated with plate waste. The better of taste food, the less plate waste.

Keywords: plate waste, taste of food, timetable of distribution 


\author{
*Koresponden: \\ arinda@polije.ac.id \\ 1,2Prodi Gizi Klinik, Jurusan Kesehatan, Politeknik Negeri Jember, Jl. Mastrip no. 164, Jember, Jawa Timur, Indonesia
}

\section{PENDAHULUAN}

Tuntutan pasien terhadap pelayanan gizi di rumah sakit semakin tinggi. Pasien menghendaki pelayanan gizi yang optimal terutama dalam hal penyajian makanan. Saat ini, pelayanan gizi sudah berkembang sejalan dengan kemajuan ilmu dan teknologi di bidang gizi dan kuliner rumah sakit. Namun, masalah penerimaan makanan oleh pasien masih banyak terjadi. Daya terima terhadap makanan rumah sakit ditunjukkan dengan banyak sedikitnya makanan yang tersisa. Sisa makanan menjadi indikator untuk mengevaluasi kepuasan pasien terhadap kegiatan penyelenggaraan makanan rumah sakit ${ }^{12}$. Penyelenggaraan makanan merupakan pelayanan gizi yang bertanggungjawab atas tersedianya makanan yang bermutu dan tepat diet dimana makanan yang dihidangkan kepada pasien telah disesuaikan dengan status klinis dan dihitung kebutuhan zat gizinya serta menerapkan prinsip efisiensi biaya, aman dan dapat diterima pasien. Kegiatan ini diawali dari perencanaan menu sampai pendistribusian makanan. Tujuannya untuk memperbaiki status gizi dan mendukung proses penyembuhan penyakit. Keberhasilan penyelenggaraan makanan mengacu pada standar pelayanan minimal dimana sisa makanan yang tidak dikonsumsi pasien maksimal $20 \% 1,3$.

Standar sisa makanan rumah sakit di Indonesia $\leq 20 \%$. Kisaran angka ini juga menjadi standar sisa makanan rumah sakit di Inggris dan Australia². Banyaknya makanan yang tersisa mengakibatkan ketidaksesuaian asupan dengan kebutuhan gizi pasien selama pasien dirawat. Meskipun sebagian besar rumah sakit telah menyajikan makanan sesuai selera dan kebutuhan pasien tapi masih banyak pasien yang merasa kurang puas terhadap makanan yang disajikan sehingga terjadi sisa makanan $\geq 20 \%$. Tingginya sisa makanan merupakan masalah serius yang perlu mendapat perhatian khusus karena berkontribusi menyebabkan kejadian malnutrisi di rumah sakit. Selain itu, jumlah sisa makanan yang tinggi juga berakibat pemborosan anggaran biaya makan di rumah sakit ${ }^{4}$. Sebuah studi yang dilakukan Simzari (2017) terhadap 120 orang pasien dengan lama perawatan $8,9 \pm 3,5$ hari, rata-rata asupan energi $(1326 \pm 681,44 \mathrm{kkal} / \mathrm{hari})$ dan proteinnya $(66,81 \pm 31,66 \mathrm{gr} / \mathrm{hari})$ belum memenuhi kebutuhan energi $(2030 \pm 409,03 \mathrm{kkal} / \mathrm{hari})$ dan protein $(76,13 \pm$ $15,33 \mathrm{gr} /$ hari) karena rata-rata sisa makan siang $(37,7 \pm 29,88 \%)$ dan sisa makan malam $(30,4 \pm 23,61 \%)$ masih tinggi. Akibatnya, terjadi penurunan berat badan yang tidak disengaja $>10 \%$ dengan prevalensi malnutrisi $12,5-14,2 \%$ selama pasien di rawat ${ }^{5}$.

Menurut beberapa penelitian, tingginya sisa makanan dapat terjadi pada pasien obsgyn dan bedah. Gambaran sisa makanan hasil riset Puruhita et al (2014) menunjukkan sisa makanan 30 pasien di ruang perawatan penyakit dalam, bedah dan kebidanan RSUD dr. Karyadi Semarang masih tinggi yaitu $\geq 75 \%{ }^{6}$. Rata-rata sisa makanan biasa pada 30 pasien bedah kelas III di RS Orthopedi Prof Dr. dr Soeharso Surakarta juga masih tinggi yaitu $30,24 \%{ }^{7}$. Begitu pula, pasien rawat inap di bangsal obgyn RS Gunung Sawo tidak menghabiskan makanan yang diberikan rumah sakit $<25 \%$ per hari ${ }^{8}$. Sebuah studi di Portugis (Dias et al, 2015), melaporkan sisa makanan pasien di ruang perawatan gastroenterologi dan bedah lebih tinggi daripada di ruang perawatan psikiatri 9 .

Banyak sedikitnya sisa makanan dapat bervariasi pada tiap jadwal penyajian makanan. Faktor yang mungkin menyebabkan makanan sisa adalah citarasa makanan. Citarasa makanan terdiri dari penampilan dan rasa makanan ${ }^{1}$. Keduanya perlu diperhatikan untuk menghasilkan makanan yang menarik, berbau sedap dan memberikan rasa yang sesuai. Penampilan makanan yang menarik akan meningkatkan selera makan pasien dalam mengkonsumsi makanan yang dihidangkan oleh rumah sakit. Rasa makanan akan ditentukan oleh rangsangan terhadap indera penciuman dan pengecapan. Dampak kepuasan yang rendah terhadap citarasa makanan mengakibatkan sisa pada makanan yang diberikan ${ }^{10}$. Menurut hasil penelitian Sitoayu et al (2016), ada perbedaan yang bermakna $(p=0,001)$ terhadap daya terima lauk hewani pada pasien bedah berdasarkan citarasa makanan yang disajikan. Citarasa yang baik dapat meningkatkan daya terima pasien $(\mathrm{OR}=0,761)^{11}$.

Ketepatan jadwal distribusi makanan juga dapat mempengaruhi sisa makanan. Ketepatan distribusi makanan berhubungan dengan metabolisme tubuh dan siklus biologis. Manusia merasa lapar setelah 3-4 jam makan, sehingga setelah waktu tersebut harus mendapatkan makanan baik dalam bentuk ringan atau berat. Makanan yang datang tidak sesuai dengan jadwal dapat berpengaruh terhadap daya terima makanan ${ }^{12}$. Makanan dengan waktu tunggu yang lama mengalami perubahan suhu pada saat disajikan kepada pasien, sehingga makanan menjadi tidak menarik dan menyebabkan penurunan nafsu makan ${ }^{13}$.

Hasil survey pendahuluan di RSD dr. Soebandi Jember, data sisa makanan semua pasien rawat inap termasuk bedah dan obsgyn mengalami peningkatan dari 26\% (tahun 2016) menjadi 28,9\% (tahun 2017). Persentase sisa makanan pasien menurut jenis makanan meliputi 30,7\% makanan pokok, 28\% lauk hewani, $27,7 \%$ lauk nabati, 37,6\% sayur dan 21,3\% buah (Instalasi Gizi RSD dr. Soebandi, 2017). Sedangkan standar mutu pelayanan gizi di RSD dr. Soebandi mengacu pada sisa makanan yang tidak dikonsumsi $(\leq 20 \%)$, ketepatan jadwal penyajian makan ( $290 \%$ ) dan pemberian diet yang tepat (100\%). Dengan demikian dapat dikatakan sisa makanan pasien di RSD dr. Soebandi masih melebihi standar.

Pemilihan pasien obsgyn dan bedah sebagai subyek penelitian mempertimbangkan jenis diet yang diperoleh yaitu makanan biasa. Selain itu, pada pasien obgyn dan bedah rentan mengalami malnutrisi karena 
ketidakcukupan asupan energi dan protein jika makanan yang disajikan rumah sakit tidak dihabiskan. Padahal energi dan protein sangat diperlukan untuk menunjang proses penyembuhan dan perbaikan sel maupun jaringan terutama pada pasien pasca operasi ${ }^{14}$. Protein merupakan zat gizi penting pada pasien obsgyn dan bedah. Penelitian Widjianingsih (2013), membuktikan konsumsi protein berhubungan signifikan dengan proses penyembuhan luka pasca sectio cesaria pada pasien obsgyn ${ }^{15}$.

Masalah yang dirumuskan dalam penelitian ini yaitu "Apakah ada hubungan antara jadwal distribusi dan citarasa makanan dengan sisa makanan pasien di ruang perawatan obsgyn dan bedah RSD dr. Soebandi Jember ?. Penelitian ini bertujuan untuk menganalisis hubungan jadwal distribusi makanan dan citarasa makanan dengan sisa makanan pasien yang dirawat di ruang obsgyn dan bedah. Penelitian ini perlu dilakukan guna mendapatkan informasi dan menganalisis faktor-faktor yang mempengaruhi tingginya sisa makanan di RSD dr. Soebandi terutama di ruang perawatan obsgyn dan bedah.

\section{METODE}

Penelitian ini merupakan jenis penelitian survey analitik dengan rancangan cross sectional study. Variabel yang diteliti meliputi jadwal distribusi dan citarasa makanan sebagai variabel bebas dan sisa makanan sebagai variabel terikat ${ }^{16}$. Penelitian dilaksanakan pada bulan Juli sampai Agustus 2018 di RSD. dr. Soebandi Jember. Penelitian ini telah mendapatkan ethical approval No. 1341/PL17/LL/2018 dari Komite Etik Politeknik Negeri Jember. Subyek dalam penelitian ini adalah pasien yang dirawat inap di ruang perawatan obsgyn dan bedah kelas III yang memenuhi kriteria inklusi : berusia 18-60 tahun, mendapat makanan biasa, tanpa diet khusus, tidak mengalami gangguan kesadaran dan bersedia berpartisipasi dalam penelitian. Sedangkan kriteria eksklusinya yaitu pasien dirawat kurang dari 3 hari, mendapat perubahan diet selama perawatan, sedang berpuasa dan ada gangguan fungsi indra penciuman dan pengecapan. Sampel dipilih secara non random dengan teknik purposive sampling sebanyak 51 orang ${ }^{17}$.

Data primer meliputi jadwal distribusi makanan, citarasa makanan dan sisa makanan. Jadwal distribusi makanan diperoleh dengan metode wawancara dan observasi selama 3 hari terhadap rentang waktu distribusi pada jadwal makan pagi (05.30 - 07.00 WIB), makan siang (11.30-12.30 WIB) dan makan malam (16.30-18.00 WIB) yang merupakan ketetapan di Instalasi Gizi RSD dr. Soebandi. Selanjutnya, perbedaan jadwal dengan waktu makanan sampai kepada pasien dicatat pada form ketepatan jadwal distribusi. Skor dicatat untuk 3 kali jadwal makan. Skor 1 jika keterlambatan >20 menit, skor 2 jika perbedaan jadwal dengan waktu distribusi makan 11-20 menit dan skor 3 jika perbedaan jadwal dengan waktu distribusi makan 010 menit, kemudian dimasukkan ke dalam rumus skor ketepatan jadwal dibagi 3 dikalikan 100\%. Jadwal distribusi makanan dikatakan tepat waktu jika skor $\geq 90 \% 3,18$. Citarasa makanan didapatkan dengan metode wawancara dan pengamatan langsung selama 3 hari. Penilaian dilakukan terhadap pendapat pasien tentang kesukaan pada penampilan makanan dan rasa makanan dengan panduan kuesioner citarasa makanan yang berjumlah 8 pertanyaan meliputi aspek warna, tekstur, porsi, cara penyajian, aroma, bumbu, tingkat kematangan dan suhu. Selanjutnya, jawaban diberi skor 1-4 menggunakan skala Likert. Skor 1 untuk jawaban sangat tidak suka (STS), skor 2 "tidak suka" (TS), skor 3 "suka" (S) dan skor 4 "sangat suka" (SS). Skor penilaian maksimal yaitu 48 dan minimal yaitu 12 . Jika skor nilai 36-48 berarti kesukaan terhadap citarasa makanan baik; skor nilai 24-35 berarti cukup dan skor nilai 12-23 berarti kurang ${ }^{19}$. Sisa makanan diobservasi dengan metode visual skala comstock 7 point (tidak ada makanan tersisa/habis atau 0\%, termakan hampir semua/sisa sesuap atau $5 \%$, tersisa $1 / 4$ porsi atau $25 \%$, tersisa $1 / 2$ porsi atau $50 \%$, tersisa $3 / 4$ porsi atau $75 \%$, termakan hanya sesuap atau $95 \%$ dan utuh atau $100 \%)^{20}$. Sisa makanan dikatakan sedikit jika $\leq 20 \%$ dan banyak jika $>20 \%{ }^{3}$. Sedangkan data sekunder berupa jumlah pasien dan data pasien baru diperoleh dari laporan pencatatan dan rekam medis pasien di ruang perawatan obsgyn dan bedah RSD dr Soebandi. Selanjutnya, data dianalisis dengan uji korelasi Rank Spearman untuk mengetahui apakah ada korelasi antara jadwal distribusi dan citarasa makanan dengan sisa makanan pasien dengan signifikansi $\alpha=0,05$.

\section{HASIL DAN PEMBAHASAN}

\section{Karakteristik Subyek Penelitian}

Penelitian ini melibatkan subyek sebanyak 51 pasien bedah dan obsgyn yang dirawat di ruang rawat inap kelas III RSD dr. Soebandi Jember. Rata-rata pasien berusia 37,39 $\pm 12,59$ tahun dengan usia termuda 18 tahun dan tertua 60 tahun. Ruang perawatan yang dijadikan tempat penelitian yaitu ruang mawar, seruni, edelweis dan dahlia. Pada penelitian ini, sebanyak $64,7 \%$ pasien menyisakan makanan dalam kategori banyak. Adapun distribusi karakteristik subyek penelitian dan hubungannya dengan sisa makanan ditunjukkan tabel 1 . Jenis kelamin memang bukan faktor internal yang secara langsung dapat mempengaruhi sisa makanan. Namun, jenis kelamin dapat menjadi faktor yang sangat berpengaruh dalam pemilihan jenis makanan tertentu. Laki-laki dan perempuan memiliki selera dan kesukaan atau preferensi yang berbeda ${ }^{13,23}$. Selain itu, angka kecukupan gizi pada laki-laki lebih besar daripada perempuan sehingga laki-laki cenderung dapat menghabiskan makanannya ${ }^{24}$.

Kondisi khusus yang dialami sebagian besar pasien perempuan dalam penelitian ini disebabkan karena pasien perempuan di ruang perawatan obgyn lebih banyak $(45 \%)$ dibandingkan di ruang perawatan bedah (14\%). Kebanyakan pasien obsgyn memiliki keluhan nyeri pasca melahirkan. Hal ini dapat berkontribusi dalam menyisakan makanan. Rasa sakit atau nyeri di bagian perut tersebut dapat menurunkan nafsu makan dan kemampuan menghabiskan makanan ${ }^{25}$. Nafsu makan juga merupakan faktor yang mempengaruhi sisa makanan. Pada pasien bedah, penyebab banyaknya sisa makanan bisa karena nafsu 
makan dan persiapan pra pembedahan sehingga pasien harus dipuasakan ${ }^{9,25}$. Sebuah studi di Inggris melaporkan bahwa nafsu makan yang rendah menyumbang $40 \%$ dari semua alasan pasien tidak menghabiskan makanannya ${ }^{20}$. Meskipun menurut penelitian Nafies (2016), sebanyak $85,7 \%$ pasien bedah di ruang perawatan kelas III RS Orthopedi Prof DR. R Soeharso Surakarta, tidak mempunyai keluhan disaat makan seperti mual, nafsu makan menurun dan susah menelan?. Penelitian Djamaluddin (2005), menunjukkan banyaknya sisa makanan pada pasien bedah umumnya disebabkan karena penurunan nafsu makan yang dipicu oleh stress akibat jenis penyakitnya dan pengobatan yang diterima ${ }^{21}$. Penurunan nafsu makan dapat disebabkan karena semakin memburuknya status kesehatan akibat tingginya tingkat keparahan penyakit pasien ${ }^{26}$.

Tabel 1. Distribusi Frekuensi Karakteristik Subyek Penelitian

\begin{tabular}{|c|c|c|c|}
\hline \multirow[b]{2}{*}{ Karakteristik } & \multicolumn{2}{|c|}{ Sisa Makanan } & \multirow[b]{2}{*}{$\mathbf{P}$} \\
\hline & $\begin{array}{c}\text { Sedikit } \\
\text { n (\%) }\end{array}$ & $\begin{array}{c}\text { Banyak } \\
\text { n (\%) }\end{array}$ & \\
\hline \multicolumn{4}{|l|}{ Usia (tahun) } \\
\hline $16-18$ & 1 & 2 & \\
\hline $19-29$ & 7 & 7 & 0,587 \\
\hline $30-49$ & 7 & 18 & \\
\hline $50-64$ & 3 & 6 & \\
\hline Total & 18 & 33 & \\
\hline \multicolumn{4}{|l|}{ Jenis Kelamin } \\
\hline Laki-laki & 13 & 7 & $0,001 *$ \\
\hline Perempuan & 5 & 26 & \\
\hline Total & 18 & 33 & \\
\hline \multicolumn{4}{|l|}{ Ruang } \\
\hline \multicolumn{4}{|l|}{ Perawatan } \\
\hline Obsgyn & 5 & 18 & 0,084 \\
\hline Bedah & 13 & 15 & \\
\hline Total & 18 & 33 & \\
\hline
\end{tabular}

\section{Sisa Makanan Pasien}

Rata-rata sisa makanan pasien di ruang perawatan bedah dan obsgyn RSD dr. Soebandi sebesar $27,6 \%$. Hal ini menunjukkan sisa makanan masih diatas standar $\geq 20 \%$. Hanya $35,3 \%$ pasien yang menyisakan makanan dalam kategori sedikit. Berdasarkan gambar 1. Rata-rata sisa makanan pada jadwal makan pagi dan siang lebih banyak dibandingkan sisa makanan pada jadwal makan malam. Sedangkan gambar 2 . menunjukkan kebanyakan jenis makanan yang tersisa banyak adalah makanan pokok (nasi) dan sayur baik pada saat makan pagi, siang ataupun malam. Hal ini sejalan dengan penelitian Djamaluddin et al (2005), sisa makanan pasien berbeda menurut jenis penyakitnya yaitu pada pasien bedah dan kanker lebih banyak menyisakan nasi $(p=0,035)$ dan sayur $(p=0,002)$ dibandingkan pasien dengan penyakit lain seperti ginjal, postpartum dan saraf ${ }^{21}$. Penelitian Nafies (2016), juga menyebutkan rata-rata sisa makanan paling banyak pada pasien bedah di RS Orthopedi Soeharso Surakarta yaitu nasi sebesar $24,2 \%^{7}$.
Hasil penelitian ini berbeda dengan penelitian Tanuwijaya et al (2018) yang melaporkan rata-rata sisa makanan pasien di RS Universitas Muhammadiyah Malang untuk jenis makanan pokok $54 \%$, lauk nabati $41 \%$, lauk hewani $61 \%$ dan sayur $73 \%{ }^{25}$. Menurut Sitoayu et al (2016), ada perbedaan yang bermakna daya terima terhadap lauk hewani pada pasien bedah berdasarkan nafsu makan $(p=0,001)$, kebiasaan makan $(p=0,022)$ dan citarasa makanan $(p=0,001)^{11}$.

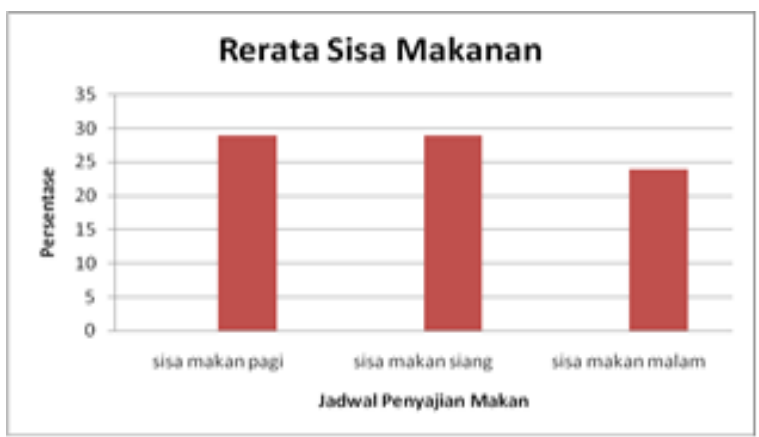

Gambar 1. Rerata Sisa Makanan Pasien di Ruang Perawatan Obsgyn dan Bedah RSD. dr. Soebandi Jember

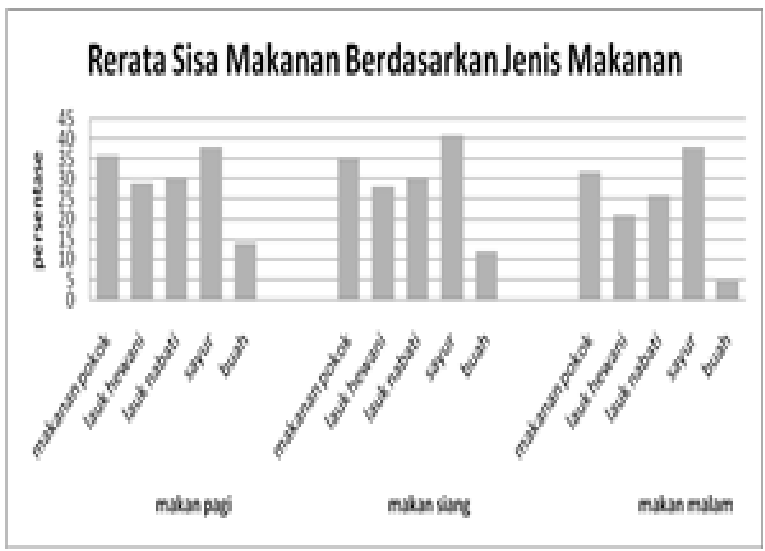

Gambar 2. Rerata Sisa Makanan Pasien Berdasarkan Jenis Makanan Pada Masing-Masing Jadwal Penyajian

Hubungan jadwal distribusi dengan sisa makanan pasien

Jadwal distribusi merupakan rentang waktu pengiriman makanan mulai dari dapur instalasi gizi sampai makanan diterima oleh masing-masing pasien di ruang perawatan. Ketepatan jadwal distribusi diukur dengan membandingkan ketepatan jam distribusi dengan jadwal makan sehari dikalikan 100\%. Jadwal distribusi makanan dikatakan tepat waktu jika kesesuaian dengan jadwal yang ditentukan instalasi gizi mencapai skor 90\%. Hasil analisis hubungan jadwal distribusi dengan sisa makanan pasien di ruang perawatan obsgyn dan bedah RSD dr. Soebandi Jember ditunjukkan pada tabel 2 .

Tabel 2 menunjukkan sebagian besar pasien menerima makanan dengan waktu distribusi yang tepat $(86,3 \%)$ dan sisa makanan pasien masih dalam kategori banyak yaitu $64,7 \%$. Sebanyak $52,9 \%$ pasien yang sisa

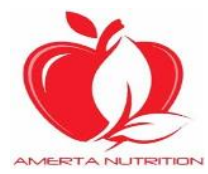


makanannya banyak justru telah mendapatkan makanan dari rumah sakit dengan waktu distribusi yang tepat. Meskipun makanan telah disajikan sesuai dengan jadwal makan pagi, siang dan malam yang ditentukan oleh RSD dr. Soebandi, namun sisa makanan pasien masih tinggi. Setelah dianalisis dengan uji spearman, diketahui bahwa jadwal distribusi makanan tidak berhubugan secara signifikan $(p=0,218, P>\alpha)$ dengan sisa makanan pasien. Hasil penelitian yang sama dilaporkan oleh Umiyati (2016) bahwa tidak ada hubungan $(p=0,377, P>\alpha)$ antara ketepatan waktu penyajian dengan sisa makanan pada pasien kelas II dan III RSUD RAA Soewondo Pati27. Begitu juga Lumbantoruan (2012), menyatakan waktu makan tidak berhubungan secara bermakna $(p=0,0604, P>\alpha)$ dengan sisa makanan ${ }^{18}$.

Tahapan aktivitas penyediaan makanan rumah sakit sesuai dengan pemesanan diet baik jumlah porsi maupun jenis makanan kepada pasien disebut distribusi makanan. Makanan diantar dan disajikan ke ruang rawat inap pasien sesuai dengan identitas dan label diet. Secara teori, ketepatan waktu distribusi makanan dapat mempengaruhi makanan yang akan disajikan tergantung dari banyaknya tenaga, jumlah peralatan dan jenis sistem distribusi makanan yang diterapkan. Ada tiga jenis sistem distribusi di rumah sakit yaitu sentralisasi (sistem terpusat), desentralisasi (sistem tidak dipusatkan) dan atau kombinasi kedua sistem sentarlisasi dan desentralisasi ${ }^{8}$.

Berdasarkan hasil pengamatan pada saat penelitian, pengolahan bahan makanan dan pemorsian di RSD. dr. Soebandi Jember dilakukan $1 / 2$ sampai 1 jam sebelum jadwal distribusi makanan sehingga makanan yang disajikan harapannya masih berpenampilan baik dan tampak fresh. Tempat pengolahan dan pemorsian makanan dilakukan pada satu ruangan yang sama. Distribusi makanan terpusat di tempat tersebut sehingga sistem distribusi yang dijalankan merupakan jenis sentralisasi. Pendistribusian makanan ke ruang perawatan obgyn dan bedah menggunakan satu troli yang sama dan tujuan pertamanya adalah ruang perawatan bedah yang terdiri dari 3 ruang yaitu mawar, seruni, edelweis. Jadi, ketidaktepatan jadwal distribusi pada minoritas pasien terjadi karena letak ruang perawatan obgyn yang lebih jauh dari pusat distribusi. Selain itu, jumlah pasien yang lebih banyak di bangsal bedah sehingga memerlukan waktu yang lebih lama untuk makanan sampai di ruang perawatan obgyn. Sedangkan, pada mayoritas pasien yang telah memperoleh makanan dengan jadwal distribusi yang tepat tapi masih meninggalkan sisa makanan yang banyak kemungkinan disebabkan karena suhu makanan, perbedaan kebiasaan jam makan dan kesukaan terhadap jenis makanan. Troli yang digunakan untuk membawa makanan belum dilengkapi dengan pemanas sehingga kemungkinan penurunan suhu dapat terjadi meskipun makanan sampai di pasien tepat waktu.

Pada saat pengambilan data, didapatkan sisa makanan banyak pada jadwal makan pagi dan siang (gambar 1). Pasien menyampaikan alasan tidak menghabiskan makan pagi karena tidak terbiasa sarapan saat di rumah dan tidak menghabiskan makan siang karena sudah makan makanan dari luar rumah sakit yang dibawakan oleh keluarga saat berkunjung sebelum jadwal makan distribusi makan siang. Sehingga pada saat pasien menerima makanan, sudah terlebih dahulu merasa kenyang. Penelitian Rabbani (2018), mengungkapkan hal yang sama bahwa rata-rata sisa makanan terbanyak pada siang hari (58\%) dikarenakan pasien mengkonsumsi makanan dari luar rumah sakit ${ }^{28}$.

\section{Hubungan citarasa makanan dengan sisa makanan pasien}

Citarasa makanan didefinisikan sebagai penilaian pendapat pasien tentang kesukaan terhadap penampilan dan rasa makanan. Pasien diwawancara dengan bantuan list pertanyaan pada kuesioner citarasa makanan. Penilaian citarasa makanan kemudian dikategorikan menjadi baik, cukup dan kurang. Adapun hubungan citarasa makanan dengan sisa makanan ditunjukkan pada tabel 3 .

Tabel 2. Hubungan jadwal distribusi dengan sisa makanan pasien

\begin{tabular}{|c|c|c|c|c|c|c|}
\hline \multirow{3}{*}{ Jadwal distribusi } & \multicolumn{4}{|c|}{ Sisa Makanan } & \multirow{3}{*}{ p value } & \multirow{3}{*}{$r$} \\
\hline & \multicolumn{2}{|c|}{ Sedikit } & \multicolumn{2}{|c|}{ Banyak } & & \\
\hline & $\mathrm{n}$ & $\%$ & $n$ & $\%$ & & \\
\hline Tepat waktu & 17 & 33,3 & 27 & 52,9 & \multirow{2}{*}{0,218} & \multirow{2}{*}{$-1,750$} \\
\hline Tidak tepat waktu & 1 & 1,96 & 6 & 11,8 & & \\
\hline Total & 18 & 35,3 & 33 & 64,7 & & \\
\hline
\end{tabular}

Keterangan: uji Rank Spearman, signifikansi $\mathrm{P}<\alpha$ dengan nilai $\alpha=0,05$

Tabel 3. Analisis hubungan citarasa makanan dengan sisa makanan

\begin{tabular}{|c|c|c|c|c|c|c|}
\hline \multirow{3}{*}{ Citarasa makanan } & \multicolumn{4}{|c|}{ Sisa Makanan } & \multirow{3}{*}{$p$ value } & \multirow{3}{*}{$r$} \\
\hline & \multicolumn{2}{|c|}{ Sedikit } & \multicolumn{2}{|c|}{ Banyak } & & \\
\hline & $n$ & $\%$ & $n$ & $\%$ & & \\
\hline Baik & 10 & 19,6 & 4 & 7,9 & & \\
\hline Cukup & 8 & 15,7 & 27 & 52,9 & 0,001 & 0,471 \\
\hline Kurang & 0 & 0 & 2 & 3,9 & & \\
\hline Total & 18 & 35,3 & 33 & 64,7 & & \\
\hline
\end{tabular}

Keterangan: * Rank Spearman, signifikansi $\mathrm{P}<\alpha$ dengan nilai $\alpha=0,05$

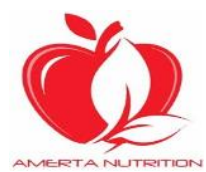


Menurut tabel 3 mayoritas subyek menilai citarasa makanan yang disajikan rumah sakit dalam kategori cukup $(68,6 \%)$ hanya 2 orang saja yang menilai citarasa makanan yang disajikan kurang. Pada subyek yang menilai citarasa makanannya baik, hampir semuanya $(71,4 \%)$ menyisakan sedikit makanan dalam piring saji/plato. Sebaliknya semua subyek yang menilai citarasa makanan yang disajikan rumah sakit kurang baik, menyisakan makanan dalam kategori banyak. Penelitian Wirasamadi (2015) juga menyampaikan hal yang sama yaitu kecenderungan pasien menyisakan makanan yang lebih sedikit apabila pasien yang menyatakan rasa dan penampilan makanan baik 4 . Pasien yang menilai penampilan makanan tidak menarik lebih banyak menyisakan makanan ${ }^{13}$.

Hasil analisis uji spearman, menunjukkan bahwa terdapat hubungan yang signifikan $(p=0,001, P<\alpha)$ antara citarasa makanan dengan sisa makanan dengan kekuatan korelasi yang cukup kuat dimana semakin baik citarasa makanan maka semakin sedikit sisa makanan. Penelitian Anggraeni (2017) juga menunjukkan hasil yang sama yaitu terdapat hubungan citarasa makanan dengan sisa makanan ${ }^{29}$. Studi yang dilakukan Wahyanta (2017) terhadap pasien rawat inap di bangsal obgyn RS Gunung Sawo Kabupaten Temanggung, juga menunjukkan bahwa terjadinya sisa makanan berhubungan dengan kepuasan pasien, penampilan makanan dan rasa makanan yang disajikan rumah sakit ${ }^{8}$. Menurut Velita (2016), citarasa makanan dengan suhu yang dapat diterima berpeluang 3,724 kali mengurangi sisa makanan dibandingkan dengan citarasa makanan dengan suhu yang kurang diterima ${ }^{30}$.

Tingkat kepuasan pasien terhadap makanan yang diberikan rumah sakit dipengaruhi oleh perbedaan kebiasaan dan pola makan di rumah, baik dalam hal rasa, besar porsi, tekstur dan susunan menu. Banyaknya sisa makan terutama dikarenakan porsi makanan pokok tidak sama dengan porsi makan saat di rumah, kecenderungan rasa olahan makanan di rumah berbeda dengan di rumah sakit. Penilaian citarasa makanan merupakan aspek yang tidak mudah dinilai secara akurat karena bersifat subyektif atau menurut selera masing-masing ${ }^{29}$. Keterbatasan dalam penelitian ini yaitu tidak dilakukan uji organoleptik dengan uji preferensi berpasangan untuk mengetahui jenis makanan tertentu yang tidak atau pun disukai. pasien

\section{KESIMPULAN}

Ketepatan waktu distribusi makanan tidak berhubungan secara signifikan dengan sisa makanan pasien. Namun, citarasa makanan berhubungan secara signifikan dengan sisa makanan pasien di ruang perawatan obsgyn dan bedah RSD dr. Soebandi Jember. Semakin baik persepsi pasien terhadap citarasa makanan maka semakin sedikit sisa makanan pasien. Pada penelitian selanjutnya diharapkan dapat menambahkan faktor internal (berasal dari pasien) yang berhubungan dengan sisa makanan seperti, stress karena perawatan medis, kondisi kesehatan (jenis penyakit) dan kemampuan makan pasien.

\section{ACKNOWLEDGMENT}

Ucapan terimakasih disampaikan kepada pihak rumah sakit daerah dr. Soebandi Jember dan secara khusus kepada semua staff di instalasi gizi yang telah membantu dan memfasilitasi pelaksanaan penelitian ini.

\section{REFERENS}

1. Irianton, A. Penyelenggaraan Makanan: Manajemen Sistem Pelayanan Gizi Swakelola dan Jasa Boga di Instalasi Gizi Rumah Sakit. (Leutica Books, 2014).

2. Soenardi, T. Mengangkat Gizi \& Kuliner Makanan Rumah Sakit. (PT Gramedia Pustaka Utama, 2014).

3. Kemenkes RI. Pedoman Pelayanan Gizi Rumah Sakit. (Kementerian Kesehatan RI, 2013).

4. Wirasamadi, N. P. P., Adhi, K. T. \& Weta, I. W. Analisis Sisa Makanan Pasien Rawat Inap di RSUP Sanglah Denpasar Provinsi Bali. Public Health Prev. Med. Arch. 3, 72-77 (2015).

5. Simzari, K., Vahabzadeh, D., Saeidlou, S. N., Khoshbin, S. \& Bektas, Y. Food intake, plate waste and its association with malnutrition in hospitalized patients. Nutr Hosp 6, 1376-1381 (2017).

6. Puruhita, N., Hagnyonowati, H., Adianto, S., Murbawani, E. A. \& Ardiaria, M. Gambaran Sisa Makanan dan Mutu Makanan Yang Disediakan Instalazi Gizi Rumah Sakit Umum Pusat dr. Kariadi Semarang. JNH J. Nutr. Health 1, (2013).

7. Nafies, D. A. A. Hubungan Cita Rasa Makanan dan Konsumsi Makanan dari Luar Rumah Sakit dengan Sisa Makanan Biasa Pada Pasien di Rumah Sakit Orthopedi Prof.DR.R.Soeharso Surakarta. (Universitas Muhammadiyah Surakarta)

8. Wahyanta. Hubungan Kepuasan PAsien Dengan Sisa Makanan Pada Pasien Rawat Inap Bangsal Obsgyn di RS Gunung Sawo Kabupaten Temanggung. (Universitas Alma Ata, 2017).

9. Dias-Ferreira, C., Santos, T. \& Oliveira, V. Hospital food waste and environmental and economic indicators - A Portuguese case study. Waste Manag. 46, 146-154 (2015).

10. Iswanto, Toto Sudargo \& Yeni Prawiningdyah. Hubungan Sisa Makanan Terhadap Lama Hari Rawat dan Biaya Pasien dengan Penjamin Jamkesmas dan Jampersal Diet Makanan Biasa di Ruang Rawat Inap Kelas III RSUD Raden Mattaher Jambi. J. Akad. Baiturrahim 5, 40-50 (2016).

11. Sitoayu, L. \& Trisia, N. Citarasa Sebagai Faktor Dominan Terhadap Daya Terima Pasien Bedah Di RSUD Cengkareng Tahun 2016. Nutr. Diaita 8, 50-57 (2016).

12. Widosari, E. \& Widiyaningsih, E. Hubungan Antara Ketepatan Jam Makan dan Frekuensi Konsumsi Makanan Dari Luar Rumah Sakit Dengan Kepuasan Pasien Yang Mendapatkan Makanan Biasa di RSUP dr Soeradji Tirtonegoro. in Seminar Nasional Gizi 2017 Program Studi Ilmu 
Gizi UMS 213 "Strategi Optimasi Tumbuh Kembang Anak" (2017).

13. Priyanto, O. H. Faktor Yang Berhubungan Dengan Terjadinya Sisa Makanan Pada PAsien Rawat Inap Kelas III di RSUD Kota Semarang. (Universitas Negeri Semarang, 2009).

14. Said, S., Taslim, N. \& Bahar, B. Gizi dan Penyembuhan Luka. (Indonesia Academic Publishing, 2013).

15. Widjianingsih, E. \& Wirjatmadi, B. Hubungan Tingkat Konsumsi Gizi Dengan Proses Penyembuhan Luka Pacaoperasi Sectio Cesarea. Media Gizi Indones. 9, 1-5 (2013).

16. Notoadmojo, S. Metodelogi Penelitian Kesehatan. (Rineka Cipta, 2012).

17. Sastroasmoro, S. Dasar-Dasar Metodelogi Penelitian KLinis. (Binarupa Aksara, 2010).

18. Lumbantoruan, D. B. S. Hubungan Penampilan Makanan dan Faktor Lainnya dengan Sisa Makanan Biasa Pasien Kelas 3 Seruni RS Puri Cinere Depok. (Universitas Indonesia, 2012).

19. Dewi, L. S. Faktor-Faktor Yang Berhubungan Dengan Sisa Makanan Pada Pasien Rawat Inap di Rumah Sakit Djatiroto Lumajang. (Universitas Jember, 2015).

20. Williams, P. \& Walton, K. Plate waste in hospitals and strategies for change. E-SPEN Eur. E-J. Clin. Nutr. Metab. 6, e235-e241 (2011).

21. Djamaluddin, M., Prawirohartono, E. \& Paramastri, I. Analisis Zat Gizi dan Biaya Sisa Makanan Pada Pasien Dengan Makanan Biasa. J. Gizi Klin. Indones. 1, 108-112 (2005).

22. Yaumah, A. N. Analisis Zat Gizi Dan Harga Plate Waste Pada Pasien Rawat Inap di RSPAD Gatot
Soebroto Ditkesad Jakarta. (Institute Pertanian Bogor, 2016).

23. Wansink, B., Cheney, M. \& Chan, N. Exploring comfort food preferences across age and gender. Physiol Behav 79, 739-747 (2003).

24. Almatsier, S. Prinsip Dasar Ilmu Gizi. (PT Gramedia Pustaka Utama, 2010).

25. Karunia Tanuwijaya, L., Gresari Sembiring, L., Yanuar Dini, C., Putri Arfiani, E. \& Arimba Wani, Y. Sisa Makanan Pasien Rawat Inap: Analisis Kualitatif. Indones. J. Hum. Nutr. 5, 51-61 (2018).

26. van Bokhorst-de van der Schueren, M., Roosemalen, M., Weijs, P. \& Langius, J. High Waste Contributes to Low Food Intake in Hospitalized Patients. Nutr. Clin. Pract. 27, 274280 (2012).

27. Umiyati, Y. S. Hubungan Ketepatan Waktu Penyajian Dan Rasa Makanan Dengan Sisa Makanan Biasa Kelas II dan III di RSUD RAA Soewondo Pati. (Universitas Muhammadiyah Surakarta, 2016).

28. Rabbani, F. Hubungan Tingkat Kematangan dengan Sisa Makanan Pokok pada Pasien Anak di RUMKITAL Dr. Ramelan Surabaya. Amerta Nutr. 2, 349-355 (2018).

29. Anggraeni, D., Ronitawati, P. \& Hartati, L. S. Hubungan Cita Rasa dan Sisa Makanan Lunak Pasien Kelas III di RSUD Berkah Kabupaten Pandeglang. Nutr. Diaita 9, 13-20 (2017).

30. Velita, S. A. Pengaruh Penyajian Dan Cita Rasa Makanan Terhadap Sisa Makanan Pasien di Rumah Sakit Umum Deli Serdang. (Universitas Sumatra Utara, 2016). 